УДК 378.147:614.842.83

DOI: $10.15330 /$ esu. $17.265-270$
Василь Ротар,

кандидат педагогічних наук, доцент, Черкаський інститут пожежної безпеки імені Героїв Чорнобиля (м. Черкаси, Україна),

Vasyl Rotar,

Candidate of pedagogical sciences ( $\mathrm{PhD})$, Associate Professor, Cherkasy Institute of Fire Safety the name of the Heroes of Chernobyl (Cherkasy, Ukraine) mnc_ok777@ukr.net

Олексій Мигаленко, кандидат економічних наук, Черкаський інститут пожежної безпеки імені Героїв Чорнобиля (м. Черкаси, Україна), Olexii Mygalenko, Candidate of economical sciences $(\mathrm{PhD})$, Cherkasy Institute of Fire Safety the name of the Heroes of Chernobyl (Cherkasy, Ukraine) muhalenko@ukr.net

\title{
ОСОБЛИВОСТІ ФОРМУВАННЯ ПІЗНАВАЛЬНОГО ІНТЕРЕСУ МАЙБУТНІХ ФАХІВЦІВ ПОЖЕЖНО-РЯТУВАЛЬНОЇ СЛУЖБИ
}

\section{PECULIARITIES OF FORMING OF COGNITIVE INTEREST OF FUTURE SPECIALISTS OF THE FIRE AND RESCUE SERVICE}

Автором доведено наявність тісного зв'язку між рівнем знань, умінь майбутніх фахівиів пожежно-рятувальної служби та сформованістю пізнавального інтересу. Виокремлено показиики результативності цодо формування пізнавального інтересу майбутніх фахівців пожежно-рятувальної служби : спрямованість освітнього прочесу на додання теорії особистісного змісту (смислові установки, особистісні смисли, мотиви); ставленнядо навчання як основного чинникапрофесійного становлення майбутнього фахівия пожежно-рятувальної служби; знання про специфіку професії фахівця пожежнорятувальної служби; чілісне сприйняття освітнього прочесу; професійна компетентність; стійкість пізнавального інтересу $і$ самостійність дій курсантів із метою розиирення власного професійного кругозору.

Ключові слова: інтерес, пізнавальний інтерес, фахівеџь пожежно-рятувальної служби, освітній проџес.

The peculiarities of formation of cognitive interest of future specialists of the fire-rescue service are analyzed in the work; Indicators of the effectiveness of this process are highlighted: the focus of the educational process on the theory of personal content (meaningful settings, personal meanings, motives); attitude to training as the main factorprofessional formation of the future specialist of the fire and rescue service; knowledge of the specifics of the profession of specialist firefighter; holistic perception of the educational process; professional competence; persistence of cognitive interest and independence of actions of cadets for the purpose of expanding their professional outlook.

It is established that the nature of the attitude of future specialists of the fire and rescue service to lectures, practical and field lessons, to independent work depends largely on how specific ideas they have about the essence of cognitive interest, scientific knowledge and their role in professional development; features of creation of conditions for independent work, self- 
education and practice of cadets. Given this fact, we have tried to find out how cadets are aware of the importance of their professional choices; the relationship between the level of their cognitive interest and the success of their professional activity.

Emphasis is placed on the existence of a close link between the level of knowledge, skills of future firefighters and the formation of cognitive interest.

The results of the survey, conducted among cadets, showed that their attitude to lectures, practical and field work, to independent work leaves much to be desired. The cadets pay little attention to both education and self-education. At the same time, interest in field trips is high.

The necessity of development of organizational and pedagogical conditions of formation of cognitive interest of future specialists of fire-rescue service is proved.

Key words: interest, cognitive interest, specialist of fire and rescue service, educational process.

Постановка проблеми у загальному вигляді. Актуальність формування пізнавального інтересу майбутніх фахівців пожежної безпеки зумовлена передовсім соціально-економічними факторами розвитку інноваційних процесів в освіті як в Україні, так і за рубежем. Для випускника закладу вищої освіти важливим $\epsilon$ усвідомлення того, що стати висококваліфікованим фахівцем можна тільки за умови грунтовного оволодіння знаннями, уміннями й навичками, необхідними для виконання професійних функцій.

Професійна діяльність фахівця пожежно-рятувальної служби є складною та багатоаспектною. В умовах сьогодення висуваються нові вимоги до фахівців пожежно-рятувальної служби, які мають досконало знати “вимоги пожежної безпеки до технологічних процесів різного призначення всіх галузей економіки країни і будьяких форм власності при їх проектуванні, будівництві, реконструкції, експлуатації та припиненні експлуатації, а також при розробці та зміні норм технологічного проектування та інших нормативних документів, що регламентують заходи щодо забезпечення пожежної безпеки на виробничих об'єктах i при розробці технологічних частин проектів, технологічних регламентів" [6]. Окрім іншого, майбутні фахівці мають бути здатними до абстрактного мислення, аналізу та синтезу, здатними вчитися та оволодівати сучасними знаннями, застосовувати знання та навички використання інформаційних технологій тощо [6].

Із урахуванням потреб сучасного ринку праці вища освіта повинна не лише сформувати у випускників (а в нашому випадку - фахівця пожежно-рятувальної служби) певний багаж знань і умінь, а й сформувати здатність до самоосвіти та самовдосконалення. А отже - сформувати пізнавальний інтерес майбутніх фахівців.

Аналіз останніх досліджень і публікацій. Дослідниками здійснюються активні пошуки шляхів підвищення якості підготовки майбутніх фахівців пожежнорятувальної служби. Так, особливості професійної підготовки майбутніх фахівців у сфері цивільного захисту на засадах компетентнісного підходу висвітлюють О. Бикова, О. Горохівський, М. Горонескуль, А. Майборода, В. Садковий та ін.

Педагогічні засади адаптації до умов професійної діяльності майбутніх фахівців пожежно-рятувальної служби у профільному вищому навчальному закладі $€$ предметом дисертаційного дослідження В. Покалюка. Дослідник доводить, що педагогічними засадами адаптації майбутніх фахівців пожежно-рятувальної служби до умов професійної діяльності є забезпечення системності, особистісно орієнтованого підходу до організації педагогічного процесу i спрямування педагогічного впливу на усвідомлення майбутніми фахівцями цілей і завдань професійної адаптації [5]. 
Особливості формування інтересу майбутніх офіцерів служби цивільного захисту до майбутньої професійної діяльності грунтовно досліджує Ю. Ненько. Дослідниця акцентує увагу на значимості інтелектуального компоненту інтересу до професії як “готовності розуму до вивчення всіх аспектів професії” [3, с. 239].

На значимості пізнавального інтересу майбутніх магістрів із пожежної безпеки у процесі формування дослідницької компетентності наголошує I. Ножко. Дослідник підкреслює, що "основа пізнавальної активності майбутніх магістрів формується насамперед у ході прослуховування навчального матеріалу під час лекції, підготовки індивідуальних дослідницьких завдань тощо. Урахування цих аспектів сприятиме розвитку почуття задоволення від озброєння майбутніми магістрами новими дослідницькими знаннями та вміннями, навичками організації своєї розумової праці" [4].

Виокремлення невирішених раніше аспектів загальної проблеми. Аналіз наукових розвідок з окресленої проблеми доводить, що незважаючи на значну увагу дослідників до питання підготовки майбутніх фахівців пожежно-рятувальної служби, пошук шляхів підвищення якості процесу формування пізнавального інтересу залишилося поза увагою дослідників.

Формулювання цілей статті. Проаналізувати особливості процесу формування пізнавального інтересу майбутніх фахівців пожежно-рятувальної служби та виокремити показники його результативності.

Виклад основного матеріалу дослідження. Для здійснення повноцінного аналізу піднятої проблеми необхідно зупинитися на 3'ясуванні сутності понять "інтерес", "пізнавальний інтерес".

Окремі аспекти теорії інтересу розкриті у наукових розвідках Б. Ананьєва, Б. Баєва, Л. Божович, Б. Додонова, О. Ковальова, С. Рубінштейна, Л. Фридмана та ін. Дослідники наголошують, що інтерес як форма прояву пізнавальної потреби забезпечує спрямованість особистості на усвідомлення цілей діяльності, а в тому числі й професійної, ознайомлення із новими ідеями, фактами тощо.

Зауважимо, що проблема інтересу продовжує бути дискусійною, однак більшість дослідників сходяться на думці, що інтерес необхідно розглядати не ізольовано, а в цілісній структурі особистості. У контексті сказаного особливо цінною для нас є думка І. Зязюна: “До основних завдань освіти можна віднести i герменевтичну, тобто уміння розумінню, яке стає важливішим способом осягнення істини" [2, с. 17]. Що й доводить актуальність питання формування пізнавального інтересу майбутніх фахівців.

У своєму дослідженні ми розглядаємо пізнавальний інтерес “як емоційно усвідомлену, вибіркову спрямованість особистості, яка звернена до предмета й діяльності, пов'язаної з ним, що супроводжується внутрішнім задоволенням від результатів цієї діяльності" [1, с. 33].

Пізнавальний інтерес, як уже зазначалося, є складною інтеграційною якістю, який знаходить свій прояв через співставлення його складників. Багатосторонність пізнавального інтересу до лекційних, практичних та виїзних занять, до самостійної роботи характеризується змістом, складністю зв'язків і відносин, що встановлюються через окремі сторони навчально-пізнавальної діяльності, іiі спрямованості, характеру змісту, форм і методів навчання. Зауважимо при цьому, що об'єктивно існуючі зв'язки між різними формами та методами як аудиторної, так i позааудиторної роботи є стрижнемінтересу до майбутньої професійної діяльності. 
У психолого-педагогічній літературі велика увага приділяється дослідженню мотиваційної сфери особистості як основного чинника активізації дій майбутнього фахівця і його професійної поведінки, що, своєю чергою, зумовлює успішність формування пізнавального інтересу, а відтак - підвищення рівня професійної компетентності. Мотив як спонукання навчально-пізнавальної діяльності знаходить свій прояв лише в тому випадку, якщо він трансформується в свідомості слухача (а в нашому випадку - майбутнього фахівця пожежно-рятувальної служби) як мета професійної діяльності. Цілі професійної діяльності визначаються умовами навчання курсантів, а характер зумовлений соціальним замовленням і потребами особистості майбутніх фахівців.

За характеромцих зв'язків і відносин можна прослідкувати динаміку рівня пізнавального інтересу майбутніх фахівців пожежно-рятувальної служби. Основними критеріями, що дозволяють говорити про результативність роботи по формуванню пізнавального інтересу майбутніх фахівців пожежно-рятувальної служби, на наше глибоке переконання, $\epsilon$ :

- спрямованість освітнього процесу на додання теорії особистісного змісту (смислові установки, особистісні смисли, мотиви);

- ставленнядо навчання як основного чинникапрофесійного становлення майбутнього фахівця пожежно-рятувальної служби;

- знання про специфіку професії фахівця пожежно-рятувальної служби;

- цілісне сприйняття освітнього процесу;

- професійна компетентність;

- стійкість пізнавального інтересу і самостійність дій курсантів із метою розширення власного професійного кругозору.

Розглядаючи пізнавальний інтерес як важливий складник успішного професійного становлення майбутнього фахівця, ми вважали за необхідне розробити програму дослідницько-експериментальної роботи, яка проводилася на базі Черкаського інституту пожежної безпеки імені Героїв Чорнобиля Національного університету цивільного захисту України.

Основною метою було з'ясування:

- характеру ставлення курсантів до лекційних, практичних та виїзних занять, до самостійної роботи;

- встановлення причин, що пояснюють негативне або пасивне ставлення майбутніх фахівців пожежно-рятувальної служби до вивчення окремих дисциплін;

- уявлень майбутніх фахівців пожежно-рятувальної служби про сутність пізнавального інтересу;

- залежності між формами, методами, засобами навчальної праці й характеромставленнямайбутніх фахівців пожежно-рятувальної служби до самостійної роботи та в ціломудо майбутньої професійної діяльності.

Встановлено, що характер ставлення майбутніх фахівців пожежно-рятувальної служби до лекційних, практичних та виїзних занять, до самостійної роботи значною мірою залежить від того, наскільки конкретні уявлення вони мають про сутність пізнавального інтересу, науково-дослідницькі знання та їх роль у професійному становленні; особливостей створення умов для самостійної роботи, самоосвіти й практики курсантів. Враховуючи цей факт, ми спробували з'ясувати, як курсанти усвідомлюють значимість свого професійного вибору; залежність між рівнем їхнього пізнавального інтересу й успішністю професійної діяльності. 
У ході дослідження нас цікавило, як процес формування пізнавального інтересу майбутніх фахівців пожежно-рятувальної служби зумовлюється розгортанням об’єкта пізнавального інтересу в освітньому процесі залученням їх до інтелектуальної праці.

3 цією метою майбутнім фахівцям пожежно-рятувальної служби пропонувалося відповісти на запитання: “Що таке “пізнавальний інтерес?”, “Чи працюєте Ви над підвищенням якості знань?", “Чи усвідомлюєте Ви залежність між рівнем пізнавального інтересу й успішністю професійної діяльності?”, “Чи усвідомлюєте Ви значимість самостійної роботи та самоосвіти у процесі професійного становлення?”, “Чи сформований у Вас інтерес до інтелектуальної праці?”. Загальну характеристику оцінкових показників пізнавального інтересу майбутніх фахівців пожежнорятувальної служби подано в таблиці 1.

Таблиця 1

Характеристика оцінкових показників пізнавального інтересу майбутніх фахівців пожежно-рятувальної служби

\begin{tabular}{|l|c|}
\hline $\begin{array}{c}\text { Оцінкові показники пізнавального інтересу майбутніх } \\
\text { фахівців пожежно-рятувальної служби }\end{array}$ & $\begin{array}{c}\text { Показники } \\
(\%)\end{array}$ \\
\hline Чи плануєте працювати за спеціальністю? & $93 \%$ \\
\hline Чи впевнені Ви в правильності вибору професії? & $93 \%$ \\
\hline Що таке “пізнавальний інтерес ?” & $34 \%$ \\
\hline Чи працюєте Ви над підвищенням якості знань? & $67 \%$ \\
\hline $\begin{array}{l}\text { Чи усвідомлюєте Ви залежність між рівнем пізнавального } \\
\text { інтересу й успішністю професійної діяльності? }\end{array}$ & $43 \%$ \\
\hline $\begin{array}{l}\text { Чи усвідомлюєте Ви значимість самостійної роботи та } \\
\text { самоосвіти у процесі професійного становлення? }\end{array}$ & $41 \%$ \\
\hline Чи сформований у Вас інтерес до інтелектуальної праці? & 42 \\
\hline
\end{tabular}

Невтішним виявився той факт, що переважна більшість майбутніх фахівців не змогли дати визначення поняття "пізнавальний інтерес", охарактеризувати його складові.

$43 \%$ опитаних курсантів заявили про усвідомлене ставлення до самостійної роботи та самоосвіти у процесі професійного становлення, що дає підстави говорити про відсутність убільшості стійкого пізнавального інтересу. Лише 42 \% опитаних вказали на наявність інтересу до інтелектуальної праці, однак основним мотивом при цьому виступає мотивація обов'язковості. Отримані результати свідчать про те, що у більшості курсантів відсутній інтерес до вивчення додаткової літератури при підготовці до практичних занять.

Причину такої ситуації слід шукати в організації освітнього процесу, недооцінці можливостей позааудиторної роботи у процесі формування пізнавального інтересу, ігноруванні викладачами цілеспрямованої й систематичної роботи щодо формування мотивації навчання, необхідності надання навчально-пізнавальному процесу особистісної спрямованості; стійкої орієнтації на самоосвіту та самовдосконалення курсантів.

Результати анкетування, проведеного серед курсантів, показали, що їх ставлення до лекційних, практичних та виїзних занять, до самостійної роботи 
залишає бажати кращого. Курсанти мало уваги приділяють як навчанню, так $\mathrm{i}$ самоосвіті. При цьому інтерес до виїзних занять $€$ високим.

Висновки. Здійснений нами аналіз наукових розвідок з окресленої проблеми, проведене дослідження дозволяють стверджувати про наявність тісного зв'язку між рівнем знань, умінь майбутніх фахівців пожежно-рятувальної служби та сформованістю пізнавального інтересу. Результати проведеного опитування курсантів Черкаського інституту пожежної безпеки імені Героїв Чорнобиля Національного університету цивільного захисту України свідчать про необхідність розробки організаційно-педагогічних умов формування пізнавального інтересу майбутніх фахівців пожежно-рятувальної служби.

Перспективи подальших наукових розвідок вбачасмо у розробці організаційно-педагогічних умов формування пізнавального інтересу майбутніх фахівців пожежно-рятувальної служби.

\section{Література}

1. Боднар А. Я., Макаренко Н. Г. Шляхи формування пізнавального інтересу особистості в процесі професійного самовизначення. Наукові записки НаУКМА. Педагогічні, психологічні науки та соиіальна робота. 2014. Т. 162. С. 32-38.

2. Зязюн І.А. Філософія педагогічної дії. Монографія Черкаси : Вид-во ЧНУ, 2008. 608 с.

3. Ненько Ю. Теоретико-методологічні засади професійно оріснтованої комунікативної підготовки майбутніх офіцерів служби цивільного захисту : дис. ... доктора пед. наук. Рівне. $2018.512 \mathrm{c}$.

4. Ножко I.O. Формування дослідницької компетентності майбутніх магістрів 3 пожежної безпеки у професійній підготовці: дис. ... канд. пед. наук. Черкаси, 2018. 245 с.

5. Покалюк В. М. Педагогічні засади адаптації до умов професійної діяльності майбутніх фахівців пожежно-рятувальної служби у профільному вищому навчальному закладі $\mathrm{c}$ предметом дисертаційного дослідження : автореф. ... канд. пед. наук. Черкаси, 2010. 22 с.

6. Стандарт професійної (професійно-технічної) освіти. Наказ Міністерства освіти $i$ науки України від "06" липня 2018 p. № 731. [Електронний ресурс]: Режим доступу https://mon.gov.ua/ua/osvita/profesijno-tehnichna-osvita/

\section{References}

1. Bodnar A. Ya., Makarenko NG Ways of forming the cognitive interest of the individual in the process of professional self-determination. NaUKMA Scientific Notes. Pedagogical, psychological sciences and social work. 2014. T. 162. P. 32-38.

2. Ziazun I.A. The philosophy of pedagogical action. Cherkasy Monograph: Issue of the National Technical University, 2008. $608 \mathrm{p}$.

3. Nenko Yu. Theoretical and methodological foundations of professionally oriented communication training of future civil defense officers: diss. ... Doctor ped. Sciences. Rivne. 2018. 512 p.

4. Nozhko IO Formation of research competence of future masters in fire safety in vocational training: diss. ... Ped. Sciences. Cherkasy, 2018. 245 p.

5. Pokolyuk VM Pedagogical principles of adaptation to the conditions of professional activity of future specialists of the fire-rescue service in a specialized higher educational institution are the subject of the dissertation research: author. ... Ped. Sciences. Cherkasy, 2010. 22 p.

6. The standard of professional (vocational) education. Order of the Ministry of Education and Science of Ukraine of July 06, 2018 N. 731. URL. https://mon.gov.ua/en/osvita/profesijno-tehnichna-osvita/

Одержано статтю: 20.09.2019

Прийнято до друку: 15.10.2019 